\title{
JK ROWLING'S THE TALES OF BEEDLE THE BARD: A MAGICAL REALISM ANALYSIS
}

\author{
Agung Wiranata Kusuma \\ UIN Maulana Malik Ibrahim Malang \\ agung.uinmaliki@gmail.com
}

\section{Abstract}

Literature plays an important role in psychological and social development of a child. Literature stimulates children's imagination and sharpens their awareness of the world around them. It teaches our children about values, norms, equity, and firmly establishes the qualities of tolerance, compassion, sharing, caring, and ability to solve conflict. Therefore, it is undeniably important to shed a light on what our children read as they will project what they read in stories through their behavior. Using a post-colonial discourse, the writer put forward a well elaborate analysis and findings of magical realism study on JK Rowling's short stories The Tales of Beedle the Bard. Moreover, the analysis focuses on how magical object describing the magical realism aspects is depicted as a part of human life and how it brings affects for the child readers.

Keywords: Magical Realism, Children Literature.

\section{INTRODUCTION}

Nowadays, there is a rapidly growing phenomenon related to the existence of children fiction. Thus, we have underlined magical realism as a new genre on children fiction which grows fast. In the recently time, the growing interest in magical realism is not only explored by the author of children fiction, but also by scholars. Magical realism is notoriously difficult to define due to its wide variety of application and it is changing through time. However, Magical realism is defined as the appearance of the supernatural in everyday life. As Zamora and Faris (1995, p.2) explain, "it is concerned with phenomenal and spiritual regions where transformation, metamorphosis, dissolution are common, where magic is a branch of naturalism, or pragmatism." They attempt to explain that there is reality existing on the other world rather than being escapists who have speculative perspectives. In the other words, magical realism endeavors to show us the view of world through other people's eyes.

However, it brings particular problems in the writing of children literature. It undeniably becomes debatable since, at the same time, it is acknowledged by some people 
as a significant decolonizing style. For example, the characters in the story are positioned unrealistically and awkwardly, in which, they are depicted in a mystic way rather than the realistic ones. The story is indeed dealing with magic. Sometimes, the author builds an understanding that one thing becomes the most important. Hence, it is commonly found unclearness in some parts of the story so that it is hard to understand by child readers.

Furthermore, in characteristics, there is no limitation between "bad" and "good", "false" and "wrong". Everyone can be both of those opposing character. So, a person can exist in dualism characteristic of "bad" and "good". Thus, it is so difficult for the children to differentiate between protagonist and antagonist. It also gives an effect that they cannot learn from the story about how people should behave. They also cannot underline what is 'do' and what is 'don' $t$ ' through understanding the characters portrayed. The characterization is too complex. Child characteristics from the modernist period exist with the clear notion of "right" and "wrong". The readers can easily differentiate who the protagonist and the antagonist. It is important that children characters discover that they had expected clear division and certain answers, yet, they instead find subtleties and uncertainty.

At the same time, unclearness is also found in the character of the story. It is often found unclearness between the magical realism's concept of reality and author imagination. For example, Alice in the Wonderland, Charlie in the Chocolate Factory, Witches in $\mathrm{Oz}$, and Lord of the Ring are strongly engaged in manipulation of setting. In Alice in the Wonderland, the imagination dominates the setting of place. Thus, the limitation between author's imagination and the concept of magical realism are being vague. It brings an admixture on it.

Meanwhile, Rowling attempts to write children's fictions which vividly manifest how magical realism has shaped and changed the representation of childhood. The Tales of Beedle the Bard, short stories by J.K Rowling, which was first published in 2007, consist of five short stories belonging to the fantasy fiction with the post-colonial paradigm. There are The Wizard and the Hoping Pot; The Fountain of Fair Fortune; The Warlock's Hairy Heart; Babbitty Rabbitty and her Cackling Stump; and The Tale of the Three Brothers. They present stories which are mostly part of the fictional world. Those five short stories tend to have similar theme.

J.K. Rowling incorporates the mystic and magic in the daily life. Beside, J.K. Rowling also brings the concept of magical object, in which, every single magical power she wrote, is embodied by the specific object as it is. However, it is still questioning about how this story could be determined as the magical realism fiction?

Thus, this paper would be focused on the characteristics which occur within the story. The three characteristics are: First, containing magic. It means that the most obvious aspect developing in the story is about magic. For example, The Fountain of Fair Fortune presents the irreducible element which goes beyond the uncanny phenomenon or event. The magical element is symbolized by fountain which has the power for answering any problems for someone who bathes there. It could be underlined that J.K. Rowling departs 
from the traditional construction of modernist childhood characters. The fantasy worlds, which the characters of The Tales of Beedle the Bard have, are both extraordinary creatures including the ones resembling human beings. This story consists of several unrealistic events beyond the reality.

Second, the presence of phenomenal world, which might be in the form of setting of places which is different from any other fantasy story. As a proof, there are not various magical settings of places or locations in the story. The story takes place in a more common place than the magical one. For instance, the setting in these five stories is truly mundane. Thus, Rowling does not lose the chance to portray reality of a world which we live in.

Third, the merging of different realm which The Tales of Beedle the Bard applied. The closeness of two realms or two worlds is shown. Rowling blends magical element and reality. As the consequence, the stories open a space of uncertainty. The narrator herself is captive between two worlds - the human and the witches - not really belong to one or the other. Thus, writing a magical realism fiction similarly sees "the relationship between magical and scientific" as the central of magical realism (Faris, 2004, p 116). In other words, Rowling does not make any limitation between two worlds-reality and magic-. However, she pretends to make a deal with mixture world rather than the parallel world. We could use the comparison from Harry Potter series, in which, the setting of J. K. Rowling's Harry Potter stories in the parallel world of Hogwarts School diminishes their likeness to magical realism. On the contrary, we could not find in The Tales of Beedle the Bard what Rowling did in Harry Potter. Therefore, The Tales of Beedle the Bard could be considered as the part of magical realism story because of its some elements.

\section{THEORETICAL FRAMEWORK}

Magical realism leaves with the understanding that this world consists of two realities, in which, both belong to the correct view of world. As Slemon (1995, p. 11) explains that there are two perspectives - the magical and the real-. Magical realism focuses on convincing us that supernatural might be the part of human logic. It is not an attempt to be dominant or being the single one of reality. However, no one is dominance. Supernatural and scientific reality might become one binary reality. Furthermore, he calls on a mixture of postmodernist assumptions to claim that magical realism is able to express a number of postcolonial elements. He also claimed that magical realism's strength is that it encodes "a concept of resistance to the massive imperial center and its totalizing system."

In addition to Slemon, Faris (2002, p. 101) in his influential article "The Question of the other: Cultural Critiques of Magical Realism", assumes that magical realism constitutes the most important trend in international contemporary fiction. Moreover, it is a wide-spread distribution, particularly among novelists like Gabriel García Márquez, Salman Rushdie, and Ben Okri. The authors of children fiction also have worked in magical realism paradigm by exploring boundary transgressions between fantastic and mimetic genres. It 
shows that magical realism in narrative texts can be differentiated by the emergence of uncanny event.

Faris (2004, p.7), on his book entitled Ordinary Enchantments Magical Realism and the Remystifiction of Narrative, suggests that there are five primary characteristics of magical realism: first, the text contains an "irreducible element" of magic; second, the descriptions in magical realism detail a strong presence of the phenomenal world; third, the reader may experience some unsettling doubts in the effort to reconcile two contradictory understandings of events; fourth, the narrative merges different realms; and, finally, magical realism disturbs received ideas about time, space, and identity.

Some scholars have explored about post-colonial in children's literature, as Chappell (2008, p. 1) discussed about how young readers are introduced to the complexities and ambiguities of the contemporary world in Harry Potter novels by J.K Rowling. He found that there is a resist of Rowling's characters to oppose the hegemony of mind and bodies through the analyzing of protagonists characters. Furthermore, Razmi \& Jamali (2012) investigated about the dominance literary mode in Toni Marrison's Beloved. They found that using the novel has become the medium to voiced the reality of Middle Passage community. Srikanth (2014), who explored Garcia Marquez's' One Hundred Years of Solitude and Salman Rushdie's Midnight's Children. He studied the importance of magic realism as a popular literary construct in selecting novels. He investigated how two writers incorporate elements of magic realism to reflect their society and culture as universal appeal.

\section{METHOD}

Different from the previous studies, this article attempts to explore magical realism portrayed in JK Rowling's short stories The Tales of Beedle the Bard. The analysis will be focused on how magical objects which describe the magical realism aspects are depicted as a part of human life and how it affects child readers in comprehending the stories.

In order to find how magical realism influences the content of children literature, we can underline some changes. The changes might appear in characters, moral values, messages, setting, language style, and so forth. For example, it is found in J.K. Rowling's novels such as Harry Potter series. The magic strongly exist in the main characters' daily live as they are uncommon people. However, there are also other common people. Probably, it would look like an odd combination between magic and daily life. Yet, Rowling attempts to convey the message that supernatural as a reality could stand in line with scientific reality at the same time. In that case, post-colonial in many ways challenges the supremacy of the rational, opening new questions regarding the limits of our reason for explaining irrational thing. It often shows uncanny events which are full of unrealistic problems.

\section{DISCUSSION}


Magical realism phenomenon greatly influences the novelists in producing works. Many novelists are interested to produce children fiction stories under the concept of magical realism. As it is commonly found, the popular novels such as One Hundred Years of Solitude, A Very Old Man with Enormous Wings, Midnight's Children, The House of the Spirits, The Governess or Little Female Academy and so forth, are strongly linked into magical realism concept. In that case, The Tales of Beedle the Bard also belongs to magical realism literature. As the strongest reason for the argument is that The Tales of Beedle the Bard strongly linked into magic existed on a mundane. J.K. Rowling departs from the traditional construction of modernist childhood characters. The fantasy worlds, which the characters of The Tales of Beedle the Bard have, are also both some extraordinary creatures including the ones resembling human beings. This story consists of several unrealistic events beyond the reality. Thus, so much uncanny and marvelous things are presented. It is engaged with a magic that strongly influences how the characters experience in their life adventure.

Looking back to the purpose of the paper, so far we found the uniqueness and the similarity on how Rowling portrays the emergences the power of magic. As we can see, Rowling always symbolize magic as an object. Thus, there is a specific reason why the authors of magical realism fiction always use an object as magical symbol. Accordingly, the aim of magical realism is to integrate various kinds of otherness such as culture and metaphysic, without reconciling their contradiction toward the current attraction about postcolonial writers in worldwide (Stephen, 2005, p. 25). Hence, in order to portray magical realism text with symbolic energies that are distinct from those in realistic text, the object used for symbolizing magic is visualized according to culture or philosophical system of belief. In short, it could be underlined that the symbolization is done for clarifying the emergence of magic both verbally and visually.

We can take an example from The Wizard and the Hoping Pot which presents the pot as the symbol of magic. It tells about how a son's of the old enchanter find his peacefulness by helping other people when they need his help through the magic pot that is given from his father after his death. In that case, the pot plays a role as fabulous creature that has great power to resolve every problem that society and the son have.

In the next story, The Fountain of Fair Fortune, the fountain is used for symbolizing the power of magic among society. Rowling positions the fountain as the greatest power in the world. They belief on it, glorify it, even, they hardly face the challenges for pursuing the fountain. Seemingly, the fountain symbolizes their happiness. As the greatest power, it brings a particular belief that the fountain could be a single thing that would resolve all of their pains. Consequently, the characters experience the magical moment closure of pursuing the fountain.

Furthermore, The Warlock's Hairy Heart labels the heart as a magical object. A young and handsome warlock who decides to never fall in love, he uses dark art to prevent himself from doing so. As long as he has a magic, he believe that he does not need anything. In that case, magic has the position of being the strongest and most powerful 
and therefore it is able to control the warlock. In the story, the heart not only symbolizes the great power of magic, but it also represents the human's nature. It seemingly brings the understanding that the heart is part of creature which has the power of rejecting something. Depend on the story, the heart does not want to bring it back into the box because he feels loneliness, sadness, illness and so forth. In other words, the heart has its free will to decide what he wants, that is more powerful than the warlock has.

On the last story, The Tale of the Three Brothers, it uses elder wand, resurrection stone and cloak of invisibility to represent magical symbols. In that case, the objects are being recuperated by the magical-realist. The world is described in a new way so that it presence can be felt through the human senses (Stephen, 2005, p.26). Thus, elder wand, resurrection stone and cloak of invisibility are used to represent the magic which could be accepted by the readers.

The emergence of magic through symbolization in a story might surely bring effect for children as consumer of literature. Therefore, the pot, the fountain, the heart, the magic stone and cloak as well as the elder wand embodied the power of magic might bring a particular doubt about the existence of magic in the world. It would bring an understanding that actually there is no magic except inanimate object. In this case, children possibly think that there is not witch anymore. Someone who called as a 'witch' basically does not have the power to create or change anything, yet, she/he is just being the owner of an inanimate object as the symbol of magic. Finally, it guides children on the confusion and uncertain of the reality of magic.

Besides, children become more sensitive to the ambiguity during their childhood. Hence, the author of children fiction should try to 'see the world as children see'. Instead, it is more important to them to write a story which is able to gain children's confidence and give the children inspiration through their creative works. It is, in other words, the imagination and creativity need to be understandable for child readers.

The symbolization of magical actually power does not merely give an ambiguity. Yet, it also brings a particular effect for children psychological development. It brings the power of imagination for children. By symbolizing the magic through an inanimate object, children could be easier to understand what and how magic is used and works. For example, in the story Babbitty Rabbitty and her Cackling Stump and The Tale of the Three Brothers, the author uses elder wand as the symbol of magical power and brings magic to life. In that case, it would help children finding belief that magic is real. The pot, fountain, heart, magic stone and elder wand come on the stage for immersing children in a magical world. It gives an opportunity for the children to enjoy their imagination and be engaged in making a belief related to magic.

Then, the understanding on how magic becomes the reality through the symbolization is supported when children directly play and imitate what the characters did in the story. Their imagination may flow by playing along and becoming part of the scenarios. For example, one scene in Babbitty Rabbitty and her Cackling Stump:

"The King climbed onto a stage in front of them, with the charlatan by his side. 
"I shall firstly make this Lady's hat disappear!" cried the King, pointing his twig at a noblewoman" (Rowling, 2007, p.68).

They may act like the king does in the story. They attempt to wave a twig to emergence a magic, even though it just happens in their imagination. As a result, it allows children to express both positive and negative emotions that probably they are unable to express in other ways. In addition, it also teaches them to take turns and developed problem solving when they are playing with other children.

Ultimately though, the purpose of the magical realist is depicting the object which emphasizes the immediate relationship between the children and the extraordinary creature. The children's reactions are equally fit for magical realism. They were not astonished but they were very, very interested. These irreducible elements are well assimilated into the realistic textual environment, rarely causing any comment by narrator or character, and become acceptable models for their readers. In accordance with that, according to Bowers (2004, p. 1), magical realism provides a perfect means for children to explore the world through their imagination without losing a connection to what they recognize in the real world.

In addition, Bowers (2004, p. 2), argues that magical realist writing children's fiction offers the opportunity for children to explore that the disruptions in their ordinary world might secure in the knowledge in which such magic and extraordinariness existed. In that case, it would be a good starting point if children learn magical realism before they learn in their adult age. Therefore, all explanation above could be the reasons why teaching magical realism to children is important to do, especially for giving the introduction and helping them to create their imagination during their childhood.

So far, children have access to many stories which allow them to accept magical realist fiction as adult does. However, in some cases, the representation of magical realism is too difficult to understand by children because it often contains various forms for the sake of entertaining adults. Meanwhile, not every children fiction follows the rules on what children understand or what children do not. Despite of all the reasons, whatever differences might exist between adult and children, contemporary sociologist of childhood urge that children be treated equally, at least in terms of admitting that children have their own views and perspectives.

\section{CONCLUSION}

In conclusion, the symbolization of magic brings particular doubt and ambiguity for the children in understanding magic. On the other side, it also brings more advantages for child readers. As it has been explained, it brings the easiness for children to understand what magic is through its symbolization.

Thus, trying to understand magic is something that never crossed children's mind. It would educate them about why it is there, how it works, why some can do it and others cannot. However, we should still be very careful on what the stories that children read 
because it would directly influence what they understand. Moreover, it will also directly determine how they observe and lead their life.

Besides, as we can see, many fantasy stories, even those that take place within our reality, have elements and worlds that are greatly removed from the everyday. Thus, something that should be noticed is that, later on J.K. Rowling attempts to convey the message of magical realism in specific way that is easily understood by child readers. There are several magical happenings in the story of The Tales of Beedle the Bard, which maintain a close connection with reality. All over, it can be concluded that The Tales of Beedle the Bard provides a good example of how magical realism is introduced by J.K. Rowling toward the children.

\section{REFERENCES}

Buckingham, D. (2000). After the death of childhood: Growing up in the age of electronic media. Cambridge: Polity Press.

Bowers, M. A. (2004). Magic(al) realism. Usa and Canada: Routledge.

Chappell, Drew. (2008). Sneaking Out After Dark: Resistance, Agency, and the Postmodern Child in JK Rowling's Harry Potter Series. Children's Literature in Education. 39. 281-293. 10.1007/s10583-007-9060-6.

Faris, W. B. (2004). Ordinary enchantments magical realism and the remystification of narrative. Nashville: Vanderbilt University Press.

Faris, W. B. (2002). The question of the other: Cultural critiques of magical realism. Arlington: The University of Texas.

Hart, S. M., \& Ouyang, W. (2005). A companion to Mmagical realism. Great Britain: Athenaeum Press Ltd, Gateshed, Tyne \& Wear.

Hollindale, P. (1997). Signs of childness in children's books. Gloucester: Thimble Press.

Hourihan, M. (1997). Deconstructing the hero: Literary theory and children's literature. London and New York: Routledge.

Lee, N. (2001). Childhood and society: Growing up in an age of uncertainty. London: Open University Press.

Loo, H. (2011). Children in postmodern literature: A reconstruction of childhood. Hohonu, $10,59-61$.

Mcguigan, J. (2006). Modernity and postmodern culture. (2nd ed.). England: Open University Press.

Rajmi, M \& Jamali, L. (2012). Magi(cal) realism as postcolonial device in toni morrison's beloved. International Journal of Humanities and Social Science, 2(5).

Rowling, J.K. (2007). The tales of beedle the bard. London: Mixed Sourced.

Slemon, Stephen (1995) Magic Realism as Postcolonial Discourse"Zamora, Lois ParkinsonFaris, Wendy B.eds. Magical Realism: Theory, History, CommunityDuke University PressDurham and London 
Srikanth, R. M. (2014). Elements of magical realism: A reading of garcia marquezs' one hundred years of solitude and salman rushdies' midnight's children. International Journal of English Language, Literature and Humanitis, 2, 2321-7065.

Strimel, C. B. (2004). The politics of terror: Rereading harry potter. Children's Literature in Education, 35, (1), 35-52.

Steenkamp, J. (2009). De-demonising universality : transcultural dragons and the universal agent in J.K. Rowling's Harry Potter and David Eddings' The Belgariad

Hart, Stephen and Ouyang, Wen-Chin, eds. (2005) A Companion to Magical Realism. Woodbridge: Tamesis.

Zamora, L. P., \& Faris, W. B. (1995). Introduction: Daquiri birds and flaubertian parrot(ie)s. In L. P. Zamora \& W. B. Faris (Eds.) Magical realism: Theory, history, community (pp. 1-11). North Carolina: Duke University Press. 
108 I Agung Wiranata Kusuma 